OPEN ACCESS

Edited by:

Christopher Rensing,

Fujian Agriculture and Forestry

University, China

Reviewed by:

Hai-Lin Zhang.

China Agricultural University, China

Nobuhiro Kaneko,

Fukushima University, Japan

${ }^{*}$ Correspondence:

Ansa Palojärvi

ansa.palojarvi@helsinki.fi

tPresent address:

Miriam Kellock,

VTT Technical Research Centre of

Finland Ltd., Espoo, Finland

Specialty section:

This article was submitted to Terrestrial Microbiology, a section of the journal

Frontiers in Microbiology

Received: 13 February 2020

Accepted: 05 October 2020

Published: 23 October 2020

Citation:

Palojärvi A, Kellock M, Parikka P, Jauhiainen L and Alakukku L (2020) Tillage System and Crop Sequence Affect Soil Disease Suppressiveness and Carbon Status in Boreal Climate.

Front. Microbiol. 11:534786.

doi: 10.3389/fmicb.2020.534786

\section{Tillage System and Crop Sequence Affect Soil Disease Suppressiveness and Carbon Status in Boreal Climate}

\author{
Ansa Palojärvi1*, Miriam Kellock ${ }^{2 \dagger}$, Päivi Parikka ${ }^{2}$, Lauri Jauhiainen ${ }^{2}$ and \\ Laura Alakukku \\ ${ }^{1}$ Natural Resources Institute Finland (Luke), Turku, Finland, ${ }^{2}$ Natural Resources Institute Finland (Luke), Jokioinen, Finland, \\ ${ }^{3}$ Department of Agricultural Sciences, University of Helsinki, Helsinki, Finland
}

The soil-borne plant pathogens cause serious yield losses and are difficult to control. In suppressive soils, disease incidence remains low regardless of the presence of the pathogen, the host plant, and favorable environmental conditions. The potential to improve natural soil disease suppressiveness through agricultural management practices would enable sustainable and resilient crop production systems. Our aim was to study the impact of autumn tillage methods and crop sequence on the soil carbon status, fungistasis and yield in boreal climate. The disease suppression was improved by the long-term reduced and no tillage management practices with and without crop rotation. Compared to the conventional plowing, the non-inversion tillage systems were shown to change the vertical distribution of soil carbon fractions and the amount of microbial biomass by concentrating them on the soil surface. Crop sequence and the choice of tillage method had a combined effect on soil organic carbon (SOC) sequestration. The improved general disease suppression had a positive correlation with the labile carbon status and microbial biomass. From the most common Fusarium species, the predominantly saprophytic $F$. avenaceum was more abundant under noninversion practice, whereas the opposite was true for the pathogenic ones. Our findings furthermore demonstrated the correlation of the soil fungistasis laboratory assay results and the prevalence of the pathogenic test fungus Fusarium culmorum on the crop cereals in the field. Our results indicate that optimized management strategies have potential to improve microbial related soil fungistasis in boreal climate.

Keywords: fungistasis, no-till, non-inversion, Fusarium spp., microbial biomass, general disease suppression, crop rotation, labile carbon

\section{INTRODUCTION}

Diseases caused by soil-borne pathogens are among the most important limiting factors for plant growth and productivity (Oerke, 2006). Due to the pathogens abilities to survive in the soil for long periods of time, even without the plant host, they cause problems worldwide (Wang and Li, 2019). Some of the soil-borne fungal pathogens produce mycotoxins, such as deoxynivalenol (DON) by Fusarium spp. (Parikka et al., 2012; Hietaniemi et al., 2016; Hofgaard et al., 2016). In modern farming, simple crop sequence, conventional tillage, and cultivation of only a limited number of crop 
varieties favor the increased incidence and severity of diseases caused by necrotrophic soil-borne pathogens (Cha et al., 2016).

The overall aim of sustainable farming is to cut down the use of pesticides (European Commission, 2017). The greater reliance on the beneficial functions and ecosystem services provided by the soil microbiome is a promising approach forward (Sipilä et al., 2012; Constanzo and Barberi, 2014; de Boer et al., 2019). Disease suppressive soils, through the competitive activity of the non-pathogenic residents of the total soil microbiota (general suppression) or the antagonistic capabilities of specific groups of microorganisms (specific suppression), are able to reduce the occurrence or severity of diseases caused by soilborne phytopathogens (Weller et al., 2002; Dignam et al., 2018). For most soil pathogens, however, the microorganisms responsible for suppression and the suppression mechanisms are not fully known, but it is likely that the soil suppressiveness is a mixture of both types of suppressiveness (Postma et al., 2008). The complex interplay of soil suppressiveness cannot simply relate to a single microbial taxon or group (de Boer et al., 2007; Legrand et al., 2019). The majority of rhizobacterial taxa indicative of the suppressiveness status of the soil may differ when comparing different types of suppressive soils or even different soils suppressive to a same phytopathogen (de Boer et al., 2019; Wang and Li, 2019).

Fungistasis is one form of soil suppressiveness, defined as the ability of the soil to restrict the germination and growth of fungi (Lockwood, 1977; Garbeva et al., 2011). The key mechanism that explains soil fungistasis is intensive competition for nutrients within the soil microbial community. Along with this, the production of antifungal compounds in different forms, including volatile organic compounds (VOC), may play a major role (Garbeva et al., 2011; van Agtmaal et al., 2018). Most likely suppressive soils are governed by microbial consortia where saprotrophic fungi have an important role (Mendes et al., 2011; Sipilä et al., 2012; Penton et al., 2014; van Agtmaal et al., 2017).

On global scale, conservation agriculture with either reduced or no tillage management, crop rotation and crop cover has increased rapidly during the last decades and was evaluated to be ca. 180 million ha in 2016 (Prestele et al., 2018; Kassam et al., 2019). Crop residues left untouched, as happens in non-inversion management, accumulates organic matter on the surface layer of soil (Muukkonen et al., 2007; Singh et al., 2015; Laine et al., 2018; Ogle et al., 2019). The carbon allocation, mixing intensity, and soil moisture and temperature conditions, affect the distribution and living conditions of microbial communities in soil. Soil and crop residue-borne plant pathogens have been reported to benefit from crop residues on the soil surface (Hofgaard et al., 2016). On the other hand, reduced tillage practices, crop species selection, diverse crop rotation and practices to increase organic matter in soils are all shown to increase the amount of microbial biomass in soil, and also tend to improve disease suppressive activity of soil (Janvier et al., 2007; Sipilä et al., 2012). However, the underlying mechanisms and the relationship between disease suppression and agrotechnological practices are still not fully understood.

In their cross-site study of soil microbial communities and Fusarium sp. fungistasis on long-term no-till and moldboard plowed treatments, Sipilä et al. (2012) ended up to a general model of interlink between low and high amount of organic matter resources for microbial metabolism together with microbial biomass and interactions. Labile carbon has been shown to be a sensitive soil quality indicator for impacts of tillage and organic matter inputs on microbial pools and activity (Bongiorno et al., 2019a,b). More studies comparing the different carbon pools [Soil Organic Carbon (SOC), labile C, microbial biomass $\mathrm{C}$ ] of soil and their contribution to the general disease suppressiveness are needed. Also, the prevalence of the actual model disease for suppression on the field needs to be studied. The emergence of soil-borne plant diseases is a result of the interactions between micro-organisms, pathogens and plants in the complex physical environment of soil. Farming practices that affect these soil qualities have potential to influence the general suppressiveness of soil against soil and residue-borne plant pathogens, and further, the crop yield. More insight is needed on the impact of reduced tillage practice and use of crop sequence.

The objectives of this study were to examine the impact of autumn tillage methods (no-till, stubble cultivation, and plowing) and crop sequence on the soil carbon status and the development of the general plant pathogen suppressiveness (test species pathogenic Fusarium culmorum fungus). The occurrence of soil and plant residue transmitted plant diseases (Fusarium spp.) were studied in a long term experimental field with two different crop sequences [spring barley (Hordeum vulgare L.) monoculture, 4-year crop rotation] in boreal climate.

\section{MATERIALS AND METHODS}

\section{Field Site and Sampling}

A long-term experimental field, located in Jokioinen in southwest Finland (coordinates $60^{\circ} 49^{\prime} \mathrm{N}, 23^{\circ} 28^{\prime} \mathrm{E}$ ), was used in the study [Regina and Alakukku, 2010 (site 2); Sipilä et al., 2012 (site $2)$ ]. The field consists of clay soil, $0-20 \mathrm{~cm}$ layer with a mean clay content of $62 \%$ and $20-40 \mathrm{~cm}$ layer with a mean clay content of $81 \%$, and is classified as a Vertic Endostagtic Cambisol (IUSS Working Group WRB, 2006). The field experiment was established in year 2000 to compare different primary tillage treatments: (i) autumn plowing (mouldboard plowed about 20$23 \mathrm{~cm}$ depth), (ii) reduced tillage (autumn stubble cultivation 10$12 \mathrm{~cm}$ ), and (iii) no-till (direct drilling in spring). Since 2011, two crop sequences were established as sub-plots to the main plots: (i) Spring barley (Hordeum vulgare) monoculture was continued, and (ii) a 4 year crop rotation system was started: spring barley (2011), faba bean (Vicia faba) (2012), spring oats (Avena sativa) (2013), spring turnip rape (Brassica rapa subsp. oleifera; 2014). The split-plot experimental design contained two factors: tillage (main-plot factor) and crop sequence (split-plot factor). Four replicates were divided into three main plots each containing two sub-plots (split plots). The three levels of the tillage factor (plowing, reduced, and no-tillage) were randomized to the main plots. The two levels of crop sequence factor (monoculture, crop rotation) were randomized to sub-plots within each three main plot. The randomizations were repeated at the four replications separately. Each sub-plot (split plot) was $9 \mathrm{~m}$ wide and $40 \mathrm{~m}$ long, a total $360 \mathrm{~m}^{2}$. 
In spring, autumn tilled treatments were sown by combined rotary harrow and drill (one-pass method, combined drill). The seedbed was prepared to $5 \mathrm{~cm}$ depth. No-tilled treatment was directly sown to $3-5 \mathrm{~cm}$ depth with combined drill having double disk coulters. Mineral fertilizers were used for barley $90 \mathrm{~N}, 3.3 \mathrm{~K}$ $\mathrm{kg} / \mathrm{ha}$, for faba bean $30 \mathrm{~N}, 1.1 \mathrm{~K} \mathrm{~kg} / \mathrm{ha}$, and for oats $60 \mathrm{~N}$, $2.2 \mathrm{~K} \mathrm{~kg} / \mathrm{ha}$ (reduced amount due to presiding $\mathrm{N}$-fixing faba bean). Weather parameters in study year 2013 (mean of years 2003-2012 in parenthesis) were: annual precipitation $562 \mathrm{~mm}$ $(656 \mathrm{~mm})$, annual mean air temperature $5.6^{\circ} \mathrm{C}\left(5.1^{\circ} \mathrm{C}\right)$, number of temperature days where ground temperature minimum $>0.0^{\circ} \mathrm{C} 195$ (184).

Composite soil samples (minimum 20 subsamples with the augers of diameter of $2 \mathrm{~cm}$ ) from each treatment plot were randomly collected in October 2013 before tillage. The soils were sampled at depths of $0-5,5-10$, and $10-20 \mathrm{~cm}$, and manually homogenized on site. Samples were divided for air drying, cold room storage $\left(+4^{\circ} \mathrm{C}\right.$ in dark) and freezer $\left(-18^{\circ} \mathrm{C}\right)$.

\section{Physical and Chemical Analyses of Soil}

The physical and chemical properties of the soil samples were analyzed as described in Regina and Alakukku (2010) and Singh et al. (2015). Soil pH and electrical conductivity (EC) were measured in water suspensions $(1: 2.5 \mathrm{v} / \mathrm{v})$. Inorganic nitrogen $\left(\mathrm{NH}_{4}-\mathrm{N}+\mathrm{NO}_{3}-\mathrm{N} ; \mathrm{N}_{\text {min }}\right)$ in soil was extracted with $1 \mathrm{M}$ $\mathrm{KCl}(\mathrm{v} / \mathrm{v}$ 1:2.5) and analyzed by Skalar autoanalyzer (SKALAR SA 40 5101). Soluble reactive phosphorus $\left(\mathrm{P}_{\text {Acetate }}\right)$ [extraction with $0.5 \mathrm{M}$ acid ammonium acetate, $\mathrm{pH}$ 4.65, Vuorinen and Mäkitie (1955)] was analyzed by spectrophotometry by molybdenum blue method.

\section{Soil Carbon Fractions}

The soil organic carbon (SOC) and total nitrogen $\left(\mathrm{N}_{\text {tot }}\right)$ content was determined from air dried, ground samples sieved through a $2 \mathrm{~mm}$ sieve and analyzed using the Leco CN-2000 analyzer (LECO, St. Joseph, MI, United States). Particulate Organic Matter Carbon (POM-C), which is the labile soil carbon fraction most available for microbes, was analyzed based on wet sieving (Cambardella and Elliott, 1992). The dry bulk density of soil was determined using the volume accurate Kopec corer with a diameter of $5 \mathrm{~cm}$ for sampling (three subsamples per plot).

The soil microbial biomass carbon $\left(\mathrm{C}_{\text {mic }}\right)$ was measured by chloroform fumigation extraction method, for which the total soluble organic carbon was determined from the $0.5 \mathrm{M} \mathrm{K}_{2} \mathrm{SO}_{4}$ extracts using a Shimadzu TOC-V CSH Total organic carbon analyzer. Results are given as soil oven-dry basis $\left(105^{\circ} \mathrm{C}, 48 \mathrm{~h}\right)$.

The total amount of SOC and $\mathrm{C}_{m i c}$ in the top soil layer was calculated two ways: by using the content of SOC and $\mathrm{C}_{\text {mic }}$ on top soil layers $(0-20 \mathrm{~cm})$ per $\mathrm{m}^{2}$ and by using the equivalent mineral soil mass method (200 kg DM soil; soil layer corresponding approx. $0-15 \mathrm{~cm}$ ) to compare the total soil C stock between the treatments (Ellert and Bettany, 1995; Wendt and Hauser, 2013; Singh et al., 2015).

\section{Fungistasis Surface Bioassay}

Fungistasis bioassay was performed using the surface method described by de Boer et al. (1998) and Sipilä et al. (2012), with slight modifications. Three replicates were measured. Fusarium culmorum was used as inoculum in fungistasis experiment because of its relevance as a common pathogen of barley and oats with soil and plant residue related dispersion (Knudsen et al., 1999). Fungistasis plates were prepared by diluting the test soil from the experimental field (soil depth $0-5 \mathrm{~cm}$ ) with a sterile claysand mixture. Sterile kaolin clay (Quality China Clay, Imerys) and sand $(0.2-1 \mathrm{~mm})(50 / 50 \%)$ was used as diluent and in the control petri dishes included in each assay. The soil 10/90\% dilution level was selected on basis of preliminary experiments. The water content of each plate was adjusted to $75 \%$ of water holding capacity of the soil mixture (fresh weight $50 \mathrm{~g}$ ). Freshly grown F. culmorum [from the growth margin on potato dextrose agar (PDA) medium] was used in the bioassay as $1.5 \mathrm{~cm}$ diameter circle and inoculated on sterile cover glass (diam. $1.8 \mathrm{~cm}$ ), placed on the test soil $(50 \mathrm{~g})$ in a petri dish $(9 \mathrm{~cm})$. The petri dishes were sealed with double wrapping of parafilm and incubated 7 days at $20^{\circ} \mathrm{C}$. The area $\left(\mathrm{cm}^{2}\right)$ of fungal growth was measured using microscopic photography. The average extension in sterile kaolin clay and sand mixture (control) was $10.8 \mathrm{~cm}^{2}$.

\section{Fusarium spp. Observations From the Crops in the Field}

Fusarium spp. contamination of developing grain was investigated three times during the growth period. Samples from the stem base were taken 2 weeks after the heading phase. To investigate Fusarium species on stem bases, whole plants were sampled (50 stems per sample) and $1 \mathrm{~cm}$ pieces of stem bases were incubated on PCNB medium (Pentachloronitrobenzene; Nash and Snyder medium; Nelson et al., 1983) at $22^{\circ} \mathrm{C}$. At the same way, Fusarium species on stubble were investigated after harvest. Fusarium contamination of harvested, dried grain was determined of 100 grains/sample.

The resulting colonies were inoculated for identification on PDA medium and cultured in the dark. Fusarium species were determined from cultures using the microscope, and contamination $\%$ values for each species were counted of the identified colonies. The most common species were the toxins forming pathogens F. culmorum (FC) and F. graminearum, (FG) and predominantly saprophytic species $F$. avenaceum (FA).

\section{Statistical Analysis}

Statistical analysis based on a split-plot experimental design (Box et al., 2005) where main plots included three different tillage treatments, while two different crop sequence systems (monoculture, and the 4 year crop rotation-system) were randomly assigned to sub-plots. The experiment included four replications (blocks). So, each response variables were analyzed using the following model:

$$
\begin{gathered}
\mathrm{y}_{\mathrm{ijk}}=\mu+\text { block }_{\mathrm{i}}+\text { tillage }_{\mathrm{j}}+\text { block }^{*} \text { tillage }_{\mathrm{ij}}+\text { sequence }_{\mathrm{k}} \\
+ \text { tillage }^{*} \text { sequence }_{\mathrm{jk}}+\varepsilon_{\mathrm{ijk}}
\end{gathered}
$$

where sequence ${ }_{k}$, tillage s $_{j}$, tillage* sequence $_{j k}$ are fixed effects of sequence, tillage treatment and their interaction, respectively. 
While block , block* $^{*}$ tillage $_{i j}$ and $\varepsilon_{i j k}$ are random effects of block, main-plot error and sub-plot error (residual). The model was fitted using SAS-software and MIXED-procedure using REML estimation method. Data from the three different depths were analyzed separately.

Assumptions about normal distribution and homogeneity of error variance was checked using box-plots of residuals and scatter plot of residual and fitted values. Some variables of fungistasis activity were normally distributed only after arcsine or square-root transformation. However, all presented estimates were transformed back to the original scale.

Correlation analysis was performed using Pearson's correlation coefficient if scatter plot of variables showed that the relationship of variables was linear, otherwise Spearman's rank-order correlation coefficient was used.

Several variables were measured from three different depths in the plot. To test differences in the magnitude of variation in the soil profiles, the coefficient of variation (CV) was calculated for each plot: (standard deviation of observations from three depths $) /($ mean of observations $) \times 100 \%$. After that, calculated $\mathrm{CV}$-values were compared statistically using the model applied to other variables.

\section{RESULTS}

\section{Chemical and Physical Properties of Soil}

In the plowed treatment, the values of the chemical and physical variables (Tables 1, 2 and Supplementary Table S1) were relatively even throughout the different top soil layers, whereas both reduced tillage and no-till had steep gradient profiles in most variables having higher values in the surface layers. Deeper in the top soil profile, the differences in mean values were small between treatments.

Crop rotation, which had been performed only two growing seasons before the soil sampling, did not markedly affect soil chemical and physical properties, compared to barley monoculture, even though the mean values were consistently higher at crop rotation. The only exception was $\mathrm{N}_{\text {min }}$, where rotation (oats after faba bean) had statistically significantly higher values than monoculture (Table 1), in spite of the reduced mineral fertilizer use for oats.

\section{Soil Organic Carbon and Microbial Biomass Carbon in the Soil Profile}

In no-till and reduced tillage treatments, soil organic carbon (SOC) content decreased by depth and formed a resource gradient for soil micro-organisms (Tables 2, 3). The gradient was especially steep in soil surface $(0-5 \mathrm{~cm}$ vs. $5-10 \mathrm{~cm})$, and steeper in no-till than in reduced tillage. On average, higher SOC content was detected on no-till $(3.36 \% \mathrm{C})$ or reduced tillage $(3.01 \% \mathrm{C})$ surface $(0-5 \mathrm{~cm})$ than plowed treatment $(2.68 \% \mathrm{C})(p<0.001)$. Very similar but even steeper profile was detected in POM-C (Particulate Organic Matter Carbon) values, carbon that is most available for soil microbes (Tables 2, 3). However, the total carbon to nitrogen ratio $(\mathrm{C} / \mathrm{N})$ of the soil stayed constant (Tables 2, 3).
The microbial biomass carbon $\left(\mathrm{C}_{m i c}\right)$ content of soil closely followed the vertical distribution of SOC and POM-C (Tables 2, 3). The top $5 \mathrm{~cm}$ on reduced and no-till treatments had clearly higher $\mathrm{C}_{m i c}$ values than plowing ( $p<0.001$; Table 3 ). Crop rotation had the tendency to increase the $\mathrm{C}_{\text {mic }}$ content of soil, as well $(p<0.07)$. The amount of $\mathrm{C}_{\text {mic }}$ separated all tillage treatments from each other both on the top-soil $(0-5 \mathrm{~cm})$ and deeper at $10-20 \mathrm{~cm}(p<0.001)$. The soil from plowing practice had the most even distribution of $\mathrm{C}_{\text {mic }}$ (CV 6.0\%; Table 2), whereas the soil from no-till fields had highest amount of $\mathrm{C}_{m i c}$ on the surface, but the strongest decline deeper in the soil (CV $30.7 \%$ ). The $\mathrm{C}_{\text {mic }}$ contains a mixture of soil microbial carbon with no separation between e.g., bacterial and fungal origin.

The total amounts of SOC and $\mathrm{C}_{\text {mic }}$ on the topsoil layer were calculated based on both fixed $0-20 \mathrm{~cm}$ depth and on the equivalent soil mass method (equivalent mineral soil mass of $200 \mathrm{~kg} \mathrm{~m}^{-2}, \approx 15 \mathrm{~cm}$ depth; Wendt and Hauser, 2013; Singh et al., 2015) which takes soil bulk density into account (Table 4). Plowed treatment contained statistically significantly less SOC

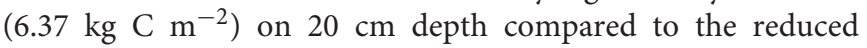
tillage and no-till treatments $\left(6.76\right.$ and $7.08 \mathrm{~kg} \mathrm{C} \mathrm{m}^{-2} ; p<0.01$, respectively). The difference turned to non-significant with the equivalent soil mass results between plow and reduced tillage (5.24, 5.29, and $5.54 \mathrm{~kg} \mathrm{Cm}^{-2}$ on plow, reduced tillage and no-till treatments, respectively). Crop rotation did not change SOC in tillage treatments (Table 4). Mean $\mathrm{C}_{m i c}$ of the treatment combinations ranged from 65.3 and $77.0 \mathrm{~g} \mathrm{C}_{\text {mic }} \mathrm{m}^{-2}$ in the soil layer equivalent to $200 \mathrm{~kg} \mathrm{~m}^{-2}$ (Table 4), which is about $1.1-1.4 \%$ of the total soil C stock.

\section{Soil Suppressiveness Activity}

Fungistasis is an inherent property of natural soil mediated mostly by soil micro-organism and it is interlinked to soil plant pathogen suppressiveness. Soil tillage methods had clear impacts on the soil fungistasis activity in the arable soil. On the top $0-5 \mathrm{~cm}$ soil, the plowing treatment had the least suppressive soil against the test fungus F. culmorum, whereas reduced and no-till treatments increased the F. culmorum fungistasis activity (Table 5). There were no statistically significant differences on fungistasis between the treatments in deeper soil layers below $5 \mathrm{~cm}$ (Fung_mm ${ }^{2}$; Supplementary Table S1).

Growth of $F$. culmorum in bioassay correlated negatively with the soil carbon fractions of SOC, POM-C and $\mathrm{C}_{m i c}$ (SOC $r=-0.34, p=0.10$; POM-C: $r=-0.40, p=0.05 ; \mathrm{C}_{\text {mic }} r=-0.40$, $p=0.06$; Figures $1 \mathrm{~A}-\mathrm{C}$ ), that is, the results correlated positively with the fungistasis activity (negative correlation with the growth of test fungus F. culmorum). The correlation was strongest with the labile carbon POM-C and weakest with the total SOC. There was no correlation between $\mathrm{C} / \mathrm{N}$ ratio and the bioassay results $(r=0.05, p=0.82$; Figure 1D).

\section{Prevalence of Soil-Borne Fusarium spp. in the Field and Crop Yield}

During the growing season 2013, repeated samplings were carried out to detect the prevalence of Fusarium spp. on cereals growing on the experimental field. The most common species 
TABLE 1 | Test results of the fixed main effects in the generalized linear mixed models for soil chemical and physical properties in soil.

\begin{tabular}{|c|c|c|c|c|c|c|}
\hline \multirow[t]{2}{*}{ Management } & \multirow{2}{*}{$\begin{array}{l}\text { Soil layer } \\
\text { Depth (cm) }\end{array}$} & \multicolumn{5}{|c|}{ Soil analysis } \\
\hline & & $\mathrm{pH}_{\mathrm{H} 2 \mathrm{O}}$ & $\mathrm{EC}\left(10^{-4} \mathrm{~S} \mathrm{~cm}^{-1}\right)$ & Bulk density $\left(\mathrm{g} \mathrm{cm}^{-3}\right)$ & $N_{\min }\left(\mathrm{mg} \mathrm{kg}^{-1}\right)$ & $P_{\text {Acetate }}\left(\mathrm{mg} \mathrm{kg}^{-1}\right)$ \\
\hline \multicolumn{7}{|l|}{ Crop sequence } \\
\hline Monoculture & $0-5$ & 6.49 & $1.01 \mathrm{a}$ & 1.14 & $7.93 \mathrm{a}$ & 20.20 \\
\hline Crop rotation & $0-5$ & 6.49 & $1.15 b$ & 1.11 & $11.38 b$ & 22.41 \\
\hline \multicolumn{7}{|l|}{ Tillage system } \\
\hline Plow & $0-5$ & 6.45 & $0.84 \mathrm{a}$ & 1.11 & $5.63 \mathrm{a}$ & $17.01(a)$ \\
\hline Reduced tillage & $0-5$ & 6.56 & $1.19 b$ & 1.13 & $11.56 b$ & $24.73(b)$ \\
\hline No-till & $0-5$ & 6.46 & $1.21 \mathrm{~b}$ & 1.15 & $11.78 b$ & $22.18(b)$ \\
\hline \multicolumn{7}{|l|}{ Crop sequence } \\
\hline Monoculture & $5-10$ & 6.43 & 0.85 & 1.28 & $6.50 \mathrm{a}$ & 15.85 \\
\hline Crop rotation & $5-10$ & 6.37 & 0.91 & 1.25 & $9.36 \mathrm{~b}$ & 17.75 \\
\hline \multicolumn{7}{|l|}{ Tillage system } \\
\hline Plow & $5-10$ & $6.43 \mathrm{a}$ & $0.82 \mathrm{a}$ & $1.22 \mathrm{a}$ & $6.76 \mathrm{a}$ & 16.39 \\
\hline Reduced tillage & $5-10$ & $6.47 \mathrm{a}$ & $0.99 b$ & $1.29 b$ & $9.54 b$ & 20.70 \\
\hline No-Till & $5-10$ & $6.30 \mathrm{~b}$ & $0.82 \mathrm{a}$ & $1.30 \mathrm{~b}$ & $7.48 \mathrm{a}$ & 13.32 \\
\hline \multicolumn{7}{|l|}{ Crop sequence } \\
\hline Monoculture & $10-20$ & 6.44 & 0.79 & 1.35 & $5.33 \mathrm{a}$ & 14.67 \\
\hline Crop rotation & $10-20$ & 6.39 & 0.83 & 1.35 & $7.56 \mathrm{~b}$ & 15.95 \\
\hline \multicolumn{7}{|l|}{ Tillage system } \\
\hline Plow & $10-20$ & 6.48 & $0.83 \mathrm{a}$ & $1.27 \mathrm{a}$ & $7.07 \mathrm{a}$ & 16.65 \\
\hline Reduced tillage & $10-20$ & 6.39 & $0.83 \mathrm{a}$ & $1.40 b$ & $6.57 \mathrm{a}$ & 16.70 \\
\hline No-till & 10-20 & 6.38 & $0.76 b$ & $1.39 b$ & $5.70 b$ & 12.57 \\
\hline
\end{tabular}

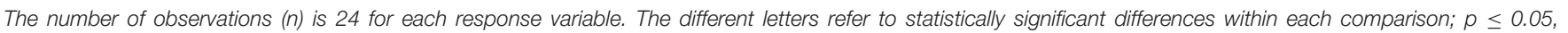
$(p \leq 0.10)$.

were F. culmorum, F. graminearum and F. avenaceum. The prevalence of the species in stem base, yield and stubble is shown in Figure 2A (monoculture; barley) and Figure 2B (crop rotation; oats). Generally, oats is seen to be especially susceptive to Fusarium spp. pathogen strains in boreal environment (Hofgaard et al., 2016), which was reflected on the results. Crop species at crop sequence (barley monoculture vs. oats at crop rotation) explained the differences in stem base $(p<0.01)$ and stubble $(p<0.06)$.

Non-inversion management decreased the occurrence of the toxins forming pathogens $F$. culmorum and F. graminearum whereas the predominantly saprophytic species $F$. avenaceum was detected more often (Figures 2A,B and Supplementary Table S2). On barley monoculture, F. graminearum was the main mycotoxin DON producer (Kaukoranta et al., 2019) in grain (harvested and dried) and stubble (collected and analyzed in September) under plowing. The toxins forming pathogen F. culmorum was the test fungus for the fungistasis surface assay (see section "Fungistasis Surface Bioassay"). Negative correlation between fungistasis activity in soil and prevalence of test fungus $F$. culmorum on stem base of crop plants was clear under monoculture ( $r=0.59, p=0.04$; Figure 3A).

Crop yield of the experiment in study year 2013 was over the average of the area [Official Statistics of Finland (2020); Supplementary Table S2, and Table 5]. From the tillage treatments, no-till produced the highest yield per hectare $(p<0.01)$, no-till with crop rotation being the best treatment combination. However, there was statistically significant correlation between crop yield and soil fungistasis only in monoculture after removal of an outlier $\left({ }^{*} r=-0.15\right.$, $p=0.03$; Figure 3B).

\section{DISCUSSION}

\section{General Disease Suppressiveness of Soil}

To our knowledge, this was the first study on the impacts of reduced and no tillage combined with crop sequence on the general disease suppressiveness of arable soil in boreal climate. The long-term reduced and no tillage management practices were shown to improve the disease suppressiveness of soil compared to conventional plowing practice. The improved disease suppressiveness was related to the improved labile carbon status, and increased microbial biomass of the soil surface layer. Our findings furthermore demonstrate the correlation of the soil fungistasis bioassay results and the prevalence of the pathogenic test fungus F. culmorum on the crop cereals in the field.

Soil-borne plant diseases are among the most important limiting factors for plant productivity in agriculture and difficult to control (Oerke, 2006). Crops lack genetic resistance to most necrotrophic pathogens (Cha et al., 2016). The possibility to improve natural soil disease suppressiveness through agricultural management practices would offer a cost effective and environmental friendly option, and show potential 
TABLE 2 | Test results of the fixed main effects in the generalized linear mixed models for soil carbon fractions.

\begin{tabular}{|c|c|c|c|c|c|}
\hline \multirow[t]{2}{*}{ Management } & \multirow{2}{*}{$\begin{array}{c}\text { Soil layer } \\
\text { Depth (cm) }\end{array}$} & \multirow[b]{2}{*}{$\operatorname{soc}^{a}(\%)$} & \multicolumn{3}{|c|}{ Soil analysis } \\
\hline & & & $\mathrm{C} / \mathrm{N}$ & POM-C & $\mathrm{C}_{\text {mic }}{ }^{\mathrm{a}}\left(\mathrm{mg} \mathrm{C} \mathrm{kg}{ }^{-1}\right)$ \\
\hline \multicolumn{6}{|l|}{ Crop sequence } \\
\hline Monoculture & $0-5$ & 2.99 & 11.38 & 69.90 & $432.4(a)$ \\
\hline Crop rotation & $0-5$ & 3.05 & 11.35 & 72.42 & $463.2(b)$ \\
\hline \multicolumn{6}{|l|}{ Tillage system } \\
\hline Plow & $0-5$ & $2.68 \mathrm{a}$ & 11.40 & $56.76 \mathrm{a}$ & $347.0 \mathrm{a}$ \\
\hline Reduced tillage & $0-5$ & $3.01 \mathrm{~b}$ & 11.46 & $73.78 b$ & $471.4 \mathrm{~b}$ \\
\hline No-till & $0-5$ & $3.36 \mathrm{c}$ & 11.23 & $82.95 \mathrm{c}$ & $524.9 \mathrm{c}$ \\
\hline \multicolumn{6}{|l|}{ Crop sequence } \\
\hline Monoculture & $5-10$ & 2.68 & 11.50 & 53.85 & 328.11 \\
\hline Crop rotation & $5-10$ & 2.76 & 11.38 & 55.48 & 339.17 \\
\hline \multicolumn{6}{|l|}{ Tillage system } \\
\hline Plow & $5-10$ & 2.69 & 11.47 & $54.99(a)$ & $313.80 \mathrm{a}$ \\
\hline Reduced tillage & $5-10$ & 2.75 & 11.75 & $56.82(a)$ & $348.25 b$ \\
\hline No-till & $5-10$ & 2.71 & 11.12 & $52.18(b)$ & $338.87 \mathrm{~b}$ \\
\hline \multicolumn{6}{|l|}{ Crop sequence } \\
\hline Monoculture & $10-20$ & 2.56 & 11.28 & 47.94 & 301.97 \\
\hline Crop rotation & $10-20$ & 2.63 & 11.38 & 50.11 & 307.83 \\
\hline \multicolumn{6}{|l|}{ Tillage system } \\
\hline Plow & $10-20$ & $2.71 \mathrm{a}$ & 11.44 & $54.22 \mathrm{a}$ & $329.62 \mathrm{a}$ \\
\hline Reduced tillage & $10-20$ & $2.48 b$ & 11.36 & $44.47 \mathrm{~b}$ & $281.93 b$ \\
\hline No-till & $10-20$ & $2.59 c$ & 11.19 & $48.37 b$ & $303.14 \mathrm{c}$ \\
\hline
\end{tabular}

aSOC, soil organic carbon; POM-C, particulate organic matter carbon; $C_{\text {mic }}$, microbial biomass carbon.

The different letters refer to statistically significant differences within each comparison; $p \leq 0.05,(p \leq 0.10)$.

The number of observations ( $n$ ) is 24 for each response variable.

TABLE 3 | Coefficient of variation (CV) for chemical, physical, and biological variables in the $0-5,5-10$, and $10-20 \mathrm{~cm}$ soil layers.

\begin{tabular}{lcccc}
\hline Variable & Plow & Reduced tillage & No-till & $\boldsymbol{p}$-value \\
\hline $\mathrm{pH}$ & $0.6 \mathrm{a}$ & $1.5 \mathrm{~b}$ & $1.5 \mathrm{~b}$ & $<0.01$ \\
$\mathrm{EC}$ & $6.2 \mathrm{a}$ & $18.1 \mathrm{~b}$ & $25.9 \mathrm{c}$ & $<0.001$ \\
Bulk Density & $7.3 \mathrm{a}$ & $11.0 \mathrm{~b}$ & $9.8(\mathrm{~b})$ & 0.03 \\
$\mathrm{~N}_{\text {min }}$ & $14.0 \mathrm{a}$ & $27.1 \mathrm{~b}$ & $37.6 \mathrm{c}$ & $<0.001$ \\
$\mathrm{P}_{\text {available }}$ & $2.4 \mathrm{a}$ & $20.4 \mathrm{~b}$ & $34.1 \mathrm{c}$ & $<0.001$ \\
SOC & $0.8 \mathrm{a}$ & $9.6 \mathrm{~b}$ & $14.3 \mathrm{c}$ & $<0.001$ \\
$\mathrm{C} / \mathrm{N}$ & 2.5 & 3.9 & 3.1 & 0.57 \\
POM-C & $4.4 \mathrm{a}$ & $25.3 \mathrm{~b}$ & $31.1 \mathrm{c}$ & $<0.001$ \\
Cmic & $6.0 \mathrm{a}$ & $26.2 \mathrm{~b}$ & $30.7 \mathrm{c}$ & $<0.001$ \\
\hline
\end{tabular}

The different letters refer to statistically significant differences within each comparison; $p \leq 0.05$, $(p \leq 0.10)$.

to the sustainable and resilient crop production system (BaileySerres et al., 2019). Non-inversion management (reduced and no tillage) with and without crop rotation improved soil fungistasis compared to plowed barley monoculture in boreal climate. Previously, van Agtmaal et al. (2018) suggested that the natural pathogen suppression by volatile compounds produced by soil microbes can be promoted via management. Suppression of the pathogen Rhizoctonia solani was most related to the organic matter content of soil, whereas suppression of Fusarium oxysporum was driven by field management of reduced tillage. Also, Friberg et al. (2019) found that OTUs (Operational Taxonomic Unit) representing putative plant pathogens Fusarium culmorum/graminearum were less abundant after non-inversion tillage.

Sharma-Poudyal et al. (2017) concluded that tillage practices have a profound impact on soil fungal communities in agricultural systems. Their results suggest that taxa more common in no-till are more suited to exploit decaying roots as a food source and potentially perform as root endophytes. The fungi would get an advantage in competition for colonizing the dying root. However, another possibility is that tillage is a mechanical disturbance to the fungal populations and hyphal networks, and they are negatively impacted by it. Sipilä et al. (2012) showed that the total microbial biomass was depth dependent in no-till, i.e., no-till accumulated microbial biomass in the surface soil but not in plowed fields and that the strong difference could be seen especially in fungal biomass. Despite that the fungal biomass was not separately measured in the current study, it is very likely that the no-till surface soil, with strongest fungistasis activity, accommodated a microbial consortia with accelerated proportion of saprotrophic fungi (Sipilä et al., 2012; van Agtmaal et al., 2017). Friberg et al. (2019) pointed out that the tillage systems have a significant effect on fungal community already in the first year with non-inversion tillage. The effects on fungal community and crop performance should be considered in relation to the crop sequence used. 
TABLE 4 | Test results of the fixed main effects in the generalized linear mixed models for soil carbon pools in soil.

\begin{tabular}{|c|c|c|c|c|}
\hline \multirow[t]{2}{*}{ Management } & \multicolumn{4}{|c|}{ Soil carbon pools* } \\
\hline & $\mathrm{SOC}_{20 \mathrm{~cm}}$ & $\mathrm{soc}_{\mathrm{eq}}$ & $\mathrm{Cmic}_{20 \mathrm{~cm}}$ & Cmic $_{\text {eq }}$ \\
\hline \multicolumn{5}{|l|}{ Crop sequence } \\
\hline Monoculture & 6.69 & 5.30 & 86.4 & 69.6 \\
\hline Crop rotarion & 6.79 & 5.42 & 88.6 & 72.4 \\
\hline \multicolumn{5}{|l|}{ Tillage system } \\
\hline Plow & $6.37 \mathrm{a}$ & $5.24 \mathrm{a}$ & $80.0 \mathrm{a}$ & $65.9 a$ \\
\hline Reduced tillage & $6.76 \mathrm{~b}$ & $5.29 \mathrm{a}$ & $88.3 b$ & $71.3 b$ \\
\hline No-till & $7.08 \mathrm{c}$ & $5.54 \mathrm{~b}$ & $94.2 \mathrm{c}$ & $75.7 \mathrm{c}$ \\
\hline
\end{tabular}

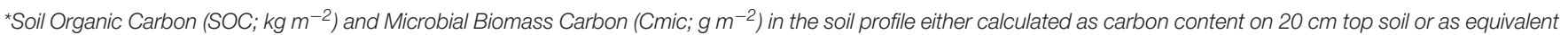

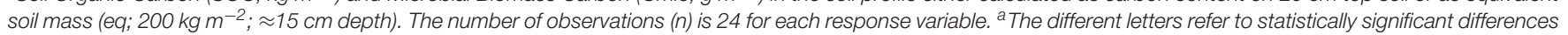
within each comparison; $p \leq 0.05$.

TABLE 5 | Test results of the fixed main effects in the generalized linear mixed models for fungistasis activity in soil $\left(\mathrm{mm}^{2}\right.$ at the surface bioassay; a smaller area indicates a stronger fungistasis) in the layer of 0-5 cm, and for yield per hectare ( $\mathrm{kg}$ $\left.\mathrm{ha}^{-1}\right)$.

\begin{tabular}{lcc}
\hline Management & Soil Fungistasis $\left(\mathbf{m m}^{\mathbf{2}}\right)$ & Yield per Hectare $\mathbf{( k g ~ h a - 1 )}$ \\
\hline Crop sequence & 338.3 & 4523 \\
Monoculture & 282.6 & 4968 \\
Crop rotation & & \\
Tillage system & $363.5 \mathrm{a}$ & $4684 \mathrm{a}$ \\
Plow & $284.4 \mathrm{~b}$ & $4440 \mathrm{a}$ \\
Reduced tillage & $283.5 \mathrm{~b}$ & $5114 \mathrm{~b}$ \\
No-till & &
\end{tabular}

The different letters refer to statistically significant differences within each comparison; $p \leq 0.05$. The number of observations $(n)$ is 24 for each response variable.

Tillage methods have a clear impact on the physical and chemical characteristics of arable soil. If the tillage is reduced, more nutrients and carbon are accumulated on the surface and less is placed to the deeper layers (Muukkonen et al., 2007; Ogle et al., 2019). Our results show that soil conditions for soil microbiome can be improved with reduced mechanical disturbance and increased amount of soil organic carbon, especially labile carbon (POM-C). This leads to improved general soil suppression. However, we did not see strong correlation between SOC content and the soil suppressiveness, which could indicate the importance of SOC quality.

In line with this, Bongiorno et al. (2019b) found that soil suppressiveness was explained by labile carbon and microbial biomass in the soil, but not by the total content of soil organic matter. Labile carbon is important for the maintenance of an abundant and active soil microbiome, essential for the function of suppressive soil. They analyzed several chemical, physical and biological soil quality indicators from the study fields across Europe. Only 25\% of the soil suppressiveness could be explained by the soil parameters measured, suggesting that other mechanisms contribute to soil suppressiveness, as well, like the presence and the activity of specific bacterial and fungal taxa with high biocontrol activity.
However, there is accumulating evidence showing the suppressive functions to be of the entire resident soil microbial community, instead of individual, beneficial microbial components (Toyota and Shira, 2018), and that the diversity of microbial taxonomic diversity is not linked to suppressiveness (Bonanomi et al., 2018). In fact, van Agtmaal et al. (2018) showed that only a small portion of natural disease suppression (caused by volatile organic compounds) was explained by microbial community attributes. Soil functionality depends on the community pattern, but not necessary in a direct way (Siegel-Hertz et al., 2018). It is possible that the activity of the microorganisms is directly involved in the targeted function (like disease suppression) only in the presence of certain other community members, without them to be directly involved in the function (Tyc et al., 2014; Williams et al., 2014; Chao et al., 2016). Plants typically lose $>21 \%$ of all photosynthate through the roots into the soil. In the same time, soil-borne pathogens and pests reduce crop yields by $\geq 5-60 \%$ annually. This is why the plant-microbe interactions in the rhizosphere required for optimal root and soil health is critical to sustainable intensification of agriculture and needs further investigations (Cha et al., 2016).

\section{Soil Labile and Organic Carbon}

The improved disease suppressiveness was related to the improved soil organic carbon status in the top surface soil and depth related soil microbial biomass gradient. Globally, the loss of soil carbon is of major concern and a goal to increase SOC stock at an annual rate of $0.4 \%$ per year (or 4 per 1000 initiative) in all land uses has been set (Soussana et al., 2019). In Finland, cultivated mineral soils have lost SOC during the latest decades, relative decrease being $0.4 \%$ yr-1. This corresponds to a C stock loss of $220 \mathrm{~kg}$ ha-1 $\mathrm{yr}-$ 1 (equivalent mineral soil mass; Heikkinen et al., 2013). The loss has been strongest in fields of continuous annual crops. Singh et al. (2015) studied the effects of tillage and straw management on soil aggregation and soil carbon sequestration in a 30-year split-plot experiment on clay soil in southern Finland. They concluded that the chances to increase topsoil carbon sequestration by reduced tillage or straw management 

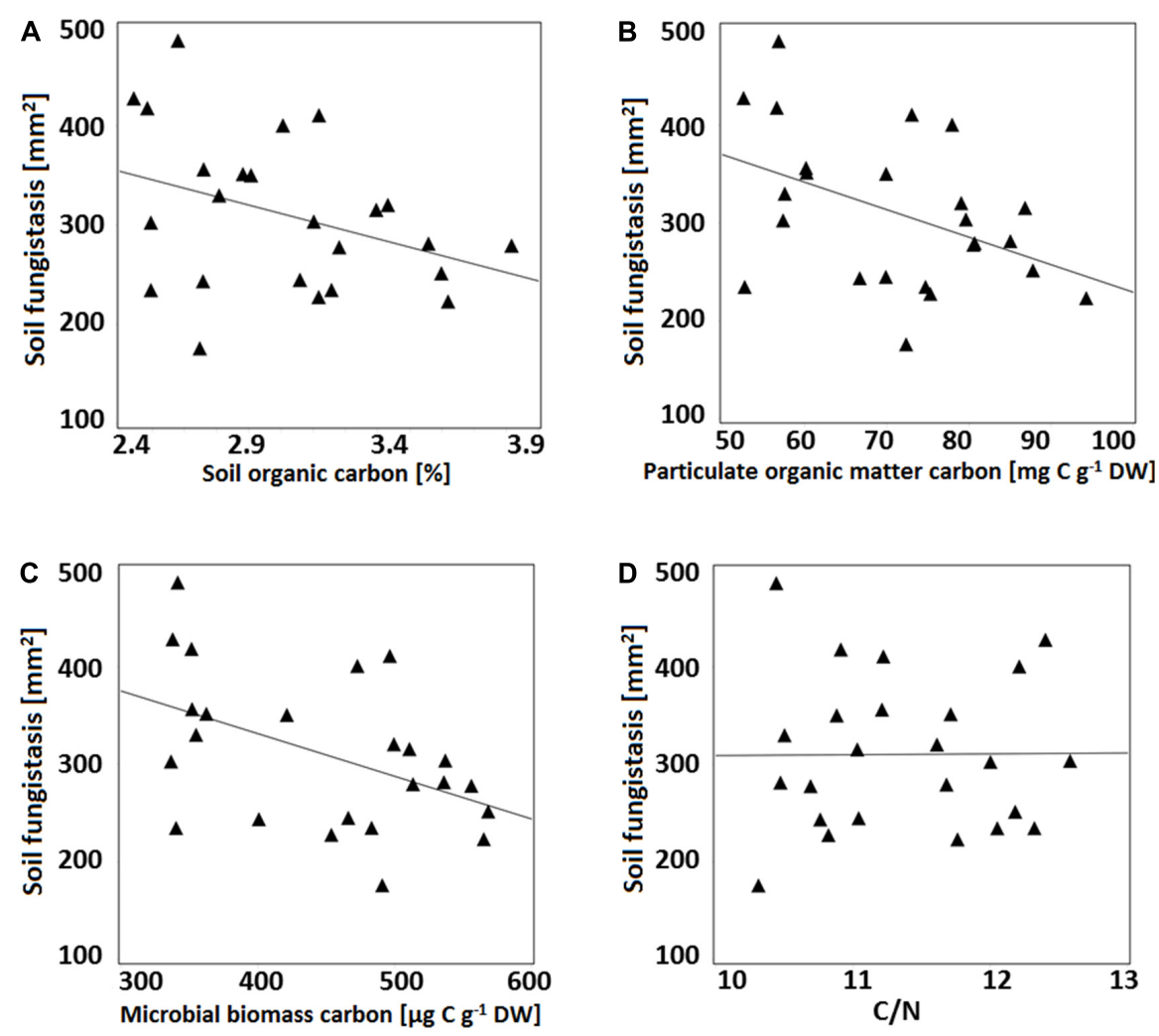

FIGURE 1 | Correlation between fungistasis activity in soil $\left(y\right.$-axis; $\mathrm{mm}^{2}$ at the surface bioassay; the smaller growth area of the test fungus $F$. culmorum, the stronger the soil fungistasis) and different top soil (0-5 cm) organic carbon fractions. (A) Soil organic carbon (SOC), \%; $r=-0.34, p=0.10)$; (B) Particulate organic matter carbon (POM-C), $\mathrm{mg} \mathrm{C} \mathrm{g}^{-1} ; r=-0.40, p=0.05$ ); (C) Microbial biomass carbon (Cmic), $\mu \mathrm{g} \mathrm{Cmic} \mathrm{g}^{-1} ; r=-0.40, p=0.06$ ), and (D) C/N (Soil total carbon to nitrogen ratio; $r=0.05, p=0.82$ ).

practices appear limited in cereal monoculture systems of the boreal region.

Our results showed a clear impact of no-tillage and reduced tillage on the organic carbon content and distribution in the arable soil. Even if the total SOC stock did not change, more carbon was concentrated on the surface $(0-5 \mathrm{~cm})$ and less carbon was placed to the deeper layers. Similarly, Ogle et al. (2019) concluded based on their extensive literature review that SOC storage can be higher under no-till management in some soil types and climatic conditions, however, uncertainties tend to be large, and no-till may be better viewed as a method for reducing soil erosion and adapting to climate change. It should be noted that SOC improves the water holding capacity of soil, which is an important feature under drought conditions. This could explain that the importance of tillage system on soil suppressiveness may vary depending on the overall soil conditions and activity.

In our study, labile carbon stock, measured both as POM-C and as microbial biomass carbon, was however, higher under notill. Even if the proportion of microbial biomass carbon is only ca. $1-2 \%$ of the total C stock, it is important to notice that the vertical distribution and high concentration on the top surface soil may be enough to cause changes in soil microbial functions.

\section{Soil Fungistasis and Prevalence of Soil-Borne Fusarium culmorum in the Field}

Fusarium head blight (FHB) disease, caused by several Fusarium species, is a serious threat on cereal yield and grain quality and is expected to benefit from future warmer and more humid climate in boreal area (Parikka et al., 2012; Hofgaard et al., 2016). According to Hofgaard et al. (2016), the increased amount of cereal residues and inoculum potential was thought to cause the increased occurrence of Fusarium mycotoxins in Norwegian cereals during the last decades, as a result of increasingly common non-inversion tillage practices. It had been a generally accepted idea that plowing practices were a tool to reduce the potential for Fusarium spp. to infect cereals. However, recently, Kaukoranta et al. (2019) concluded from a large survey data of 804 springoat fields in Finland that Fusarium spp., especially pathogenic F. culmorum, tended to be more common under plowing than under non-inversion tillage. In line with this, we found that the predominantly saprophytic $F$. avenaceum was more abundant under non-inversion practice, whereas the opposite was true for the pathogenic ones. Sipilä et al. (2012) linked high fungal biomass with high soil fungistasis activity. 
A

A 80
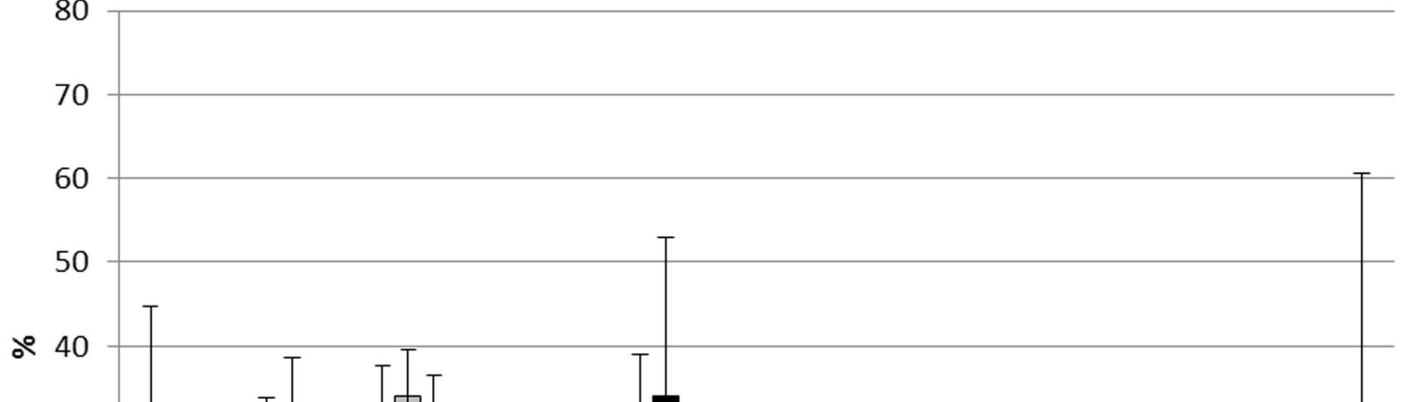

$\square$ No-Till

Monocult

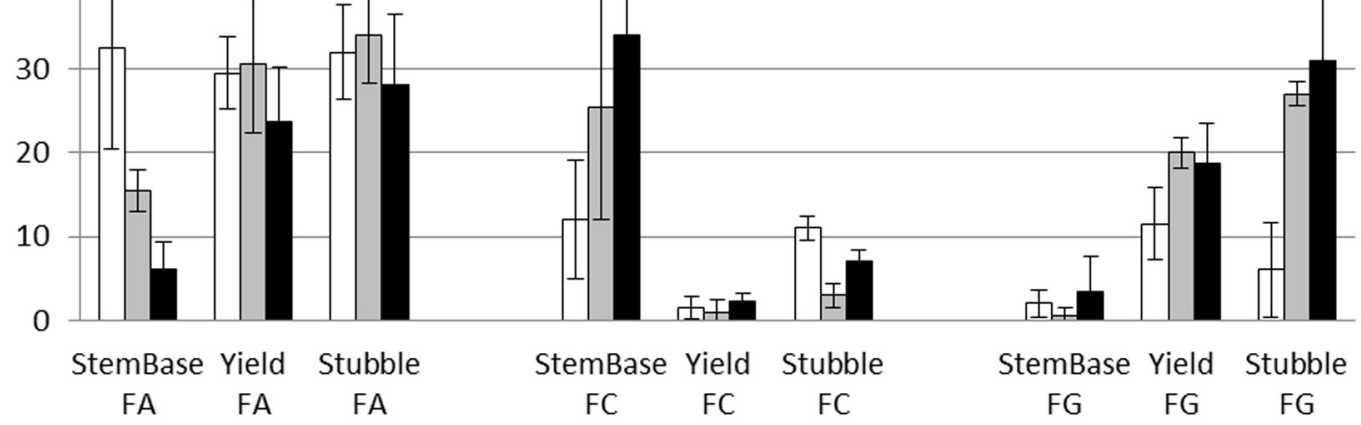

$\square$ ReducedTill

Monocult

Plough

Monocult

Prevalence of Fusarium spp.

B

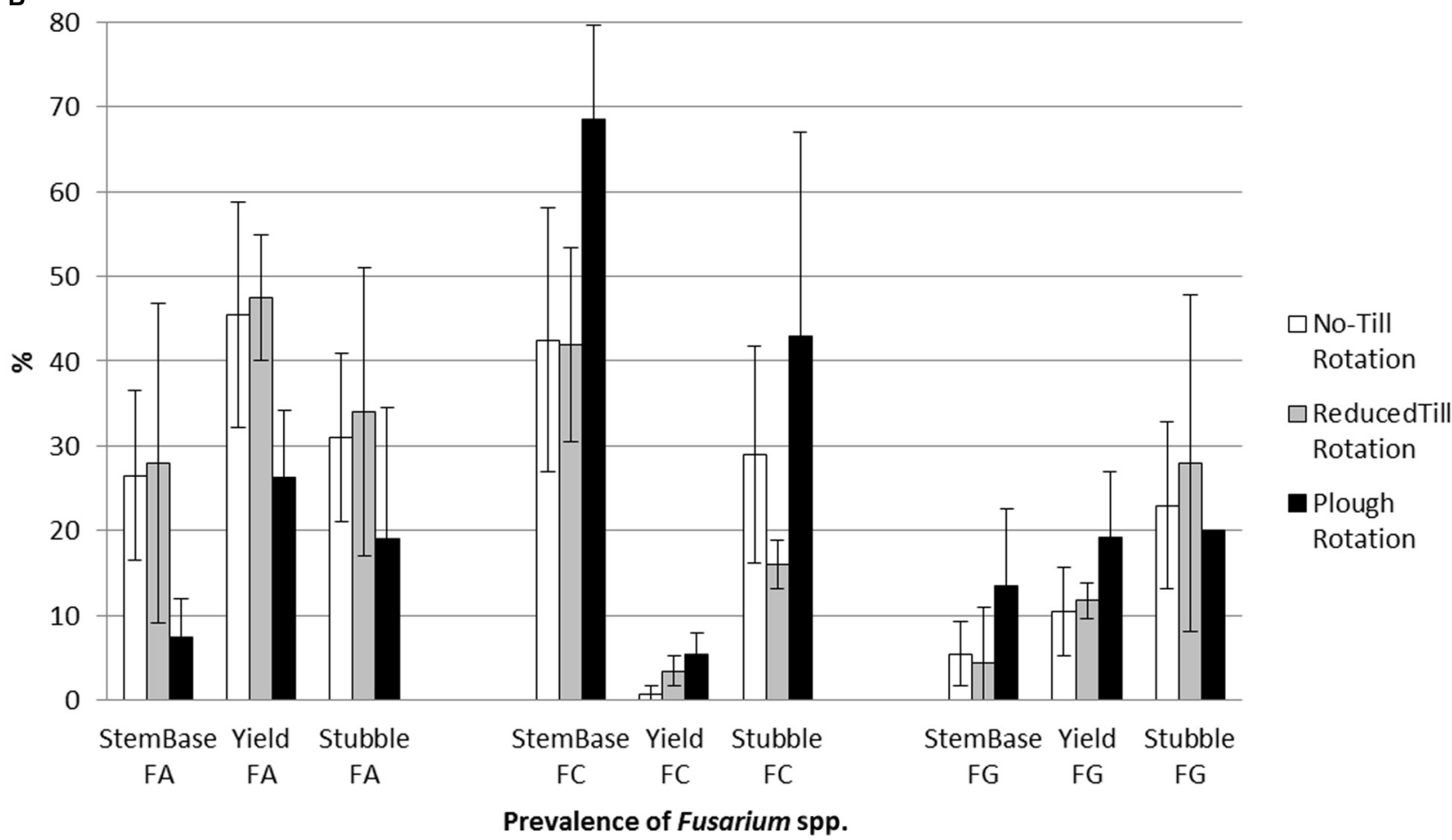

FIGURE 2 | The prevalence of toxins forming pathogens F. culmorum (FC) and $F$. graminearum (FG), and predominantly saprophytic species $F$. avenaceum (FA) on tillage treatments in (A) barley monoculture and (B) oats (crop rotation; oats is known to be more susceptible to $F$. culmorum than barley), on stem base 2 weeks after heading phase, yield during harvest, and at stubble after harvest ( $\% \pm$ SD; mean values, $N=4)$. See Supplementary Table S2 for statistical test results.

Our field observations confirmed the fungistasis bioassay results: the general plant pathogen suppressiveness of soil could be improved by agricultural management, even if the impact of specific management practice may not be directly and generally linked with the disease suppression activity (Sipilä et al., 2012; Bongiorno et al., 2019b). Our 

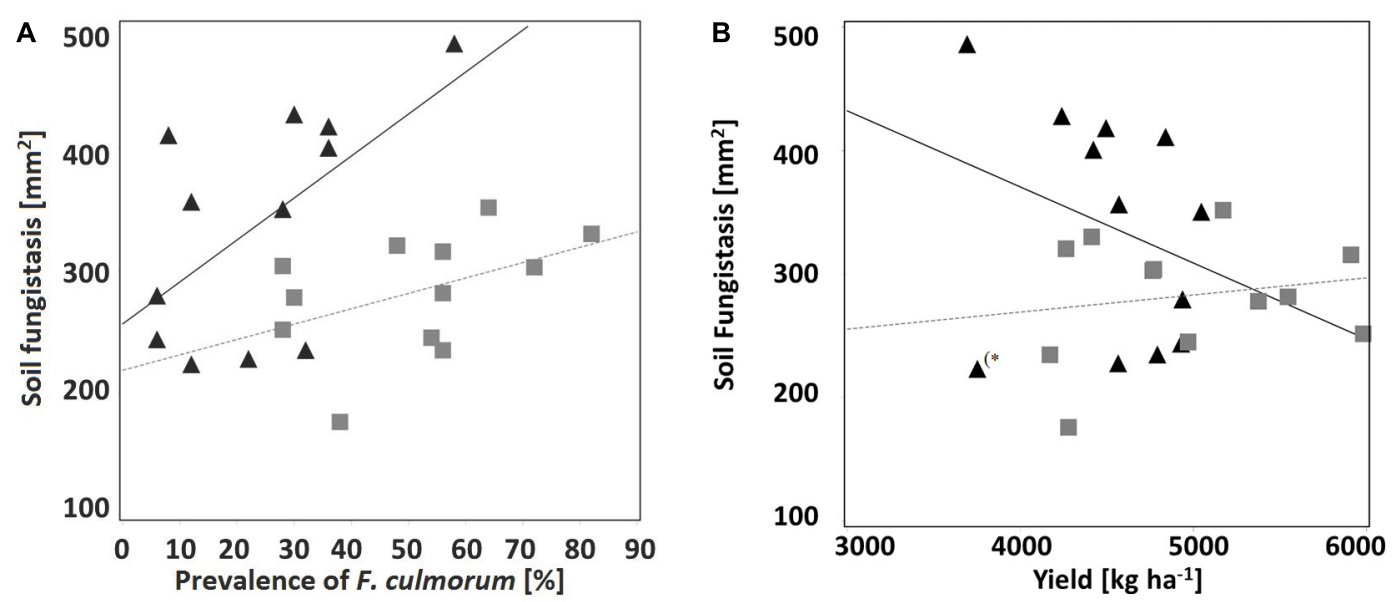

FIGURE 3 | Correlation between fungistasis activity in soil ( $y$-axis; $\mathrm{mm}^{2}$ at the surface bioassay; the smaller area - the stronger fungistasis) and (A) prevalence of test fungus $F$. culmorum ( $x$-axis; \%) on crop stem base; Triangle $=$ monoculture $(r=0.59, p=0.04)$, Square $=$ rotation (oats), $r=0.45, p=0.15$ (all tillage treatments combined), and (B) yield $\left(\mathrm{kg} \mathrm{ha}^{-1}\right)$; Triangle $=$ monoculture $\left(r=-0.29, p=0.35\right.$; without an outlier $\left.{ }^{*} r=-0.15, p=0.03\right)$, Square $=$ rotation (oats), $r=0.18, p=0.58$ (all tillage treatments combined).

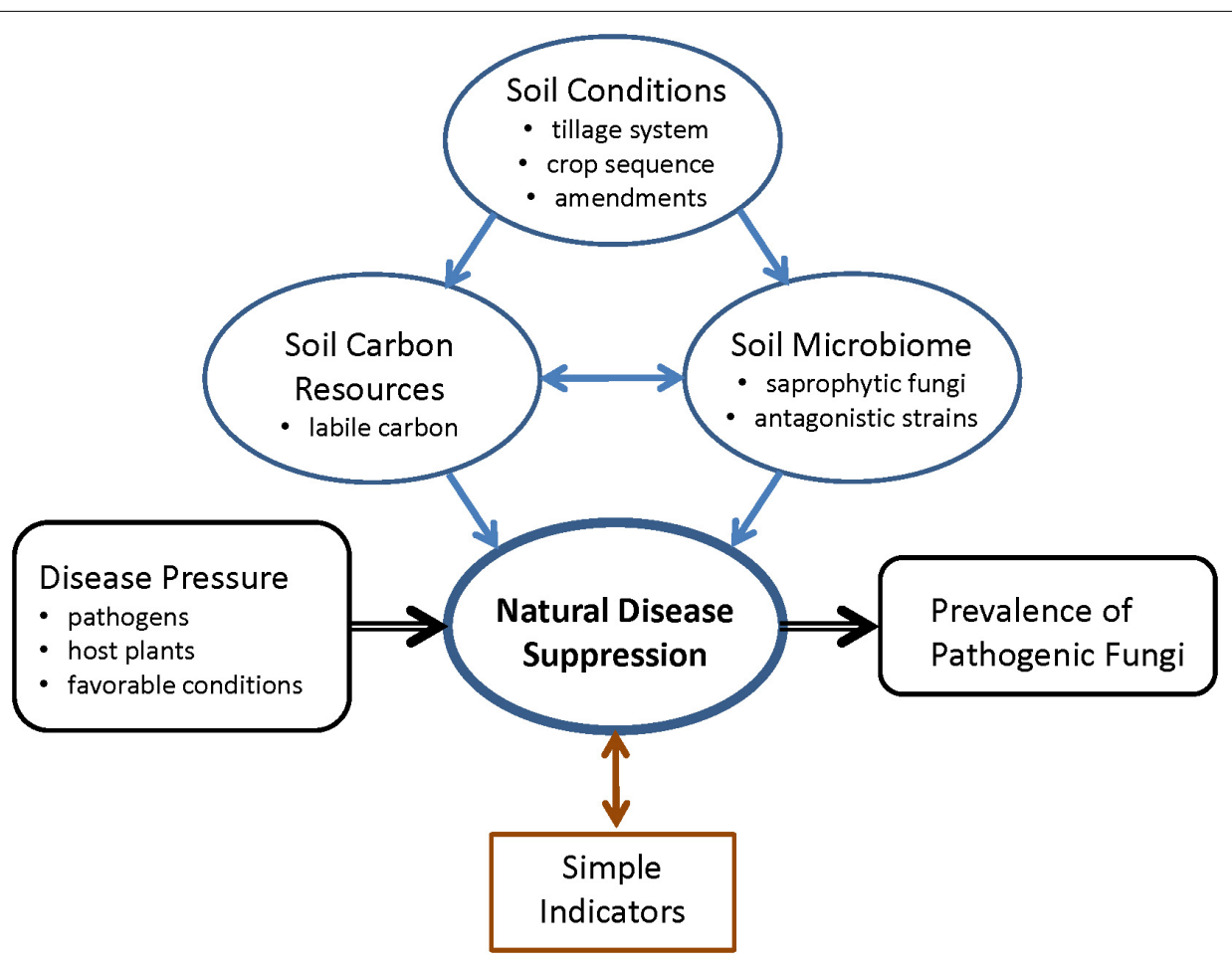

FIGURE 4 | Schematic summary of the study question, and the connections between soil conditions, soil carbon resources, soil microbiome, and natural soil disease suppression.

findings furthermore demonstrated the correlation between the laboratory surface assay for fungistasis and the prevalence of the pathogenic test fungus $F$. culmorum on the crop cereals in the field. This makes the laboratory assay a potential tool to estimate the risk of Fusarium in cereals. A clear correlation between soil fungistasis and crop yield could not be seen, even though there were indications of correlation especially in monoculture practice. Cereal yields are affected by many different factors and long-term observations would be needed to ensure the connection. However, the no-till management and crop rotation tended to increase the crop yield. The choice of agricultural management practices is proved to be a key for sustainable agricultural production. 


\section{CONCLUSION}

We demonstrated that agricultural management strategies can be applied to improve the microbial related soil ecosystem functions in the form of natural disease suppressiveness in boreal climate (Figure 4). The conditions for soil microbial communities can be manipulated by the choice of appropriate tillage and crop sequence system. Non-inversion methods, especially the no-tillage management, were shown to change the vertical distribution of carbon fractions and accumulate the SOC, labile carbon and microbial biomass carbon in the soil surface layer. Crop sequence and the choice of tillage method potentially have a combined effect on improved SOC sequestration. General soil disease suppression correlated with labile carbon and microbial biomass carbon, and had a potential impact on crop production, shown as correlation with the prevalence of the test pathogen $F$. culmorum on crops and indications of correlation with yield. The soil surface fungistasis bioassay is potentially a useful tool to monitor general soil suppressiveness. In light of these results, it is crucial to take into consideration the functionality of the whole soil microbiome when planning optimal agricultural management practices.

\section{DATA AVAILABILITY STATEMENT}

All datasets generated for this study are included in the article/Supplementary Material.

\section{REFERENCES}

Bailey-Serres, J., Parker, J. E., Ainsworth, E. A., Oldroyd, G. E. D., and Schroeder, J. I. (2019). Genetic strategies for improving crop yields. Rev. Nat. 575, 109-118. doi: 10.1038/s41586-019-1679-0

Bonanomi, G., Cesarano, G., Vincenzo, A., Di Malo, C., De Filippis, F., and Scala, F. (2018). Conventional farming impairs Rhizoctonia solani disease suppression by disrupting soil food web. J. Phytopathol. 166, 663-673. doi: 10.1111/jph. 12729

Bongiorno, G., Bünemann, E. K., Oguejiofor, C. U., Meier, J., Gort, G., Comans, R., et al. (2019a). Sensitivity of labile carbon fractions to tillage and organic matter management and their potential as comprehensive soil quality indicators across pedoclimatic conditions in Europe. Ecol. Indic. 99, 38-50. doi: 10.1016/j.soilbio. 2019.03.012

Bongiorno, G., Postma, J., Bünemann, E. K., Brussaard, L., de Goede, R. G. M., Mäder, P., et al. (2019b). Soil suppressiveness to Pythium ultimum in ten European long-term field experiments and its relation with soil parameters. Soil Biol. Biochem. 133, 174-187. doi: 10.1016/j.ecolind.2018.12.008

Box, G. E. P., Hunter, J. S., and Hunter, W. G. (2005). Statistics for Experimenters: Design, Innovation, and Discovery, 2nd Edn. New York, NY: Wiley, 672.

Cambardella, C. A., and Elliott, E. T. (1992). Particulate soil organic matter changes across a grassland cultivation sequence. Soil Sci. Soc. Am. J. 56, $777-783$.

Cha, J.-Y., Han, S., Hong, H.-J., Cho, H., Kim, D., Kwon, Y., et al. (2016). Microbial and biochemical basis of a Fusarium wilt-suppressive soil. ISME J. 10, 119-129. doi: 10.1038/ismej.2015.95

Chao, Y. Q., Liu, W. S., Chen, Y. M., Chen, W. H., Zhao, L. H., Ding, Q. B., et al. (2016). Structure, variation, and co-occurrence of soil microbial communities in abandoned sites of a rare earth elements mine. Environ. Sci. Technol. 50, 11481-11490. doi: 10.1021/acs.est.6b02284

\section{AUTHOR CONTRIBUTIONS}

AP contributed to designing the experiments and writing the manuscript. AP, MK, and PP contributed to collecting the data. $\mathrm{AP}$ and $\mathrm{LJ}$ contributed to analyzing the data. LA contributed to discussing the design and analyzing the data. All authors reviewed and approved the manuscript before its submission.

\section{FUNDING}

This work was funded by the Development Fund for Agriculture and Forestry (Makera) grant 1531/03.01.02/2016, Maa- ja vesitekniikan tuki ry, and by the Academy of Finland through the DivCSA project (decision no. 316215).

\section{ACKNOWLEDGMENTS}

We thank the technical staff at Luke Jokioinen for their invaluable assistance in the field and in the laboratory, special appreciation is given to Markku Vainio, Mirva Ceder, and Marjaana Virtanen.

\section{SUPPLEMENTARY MATERIAL}

The Supplementary Material for this article can be found online at: https://www.frontiersin.org/articles/10.3389/fmicb. 2020.534786/full\#supplementary-material

Constanzo, A., and Barberi, P. (2014). Functional agrobiodiversity and agroecosystem services in sustainable wheat production. A Rev. Agron. Sustain. Dev. 34, 327-348. doi: 10.1007/s13593-013-0178-1

de Boer, W., Gunnewiek, P. J., and Woldendorp, J. W. (1998). Suppression of hyphal growth of soil-borne fungi by dune soils from vigorous and declining stands of Ammophila arenaria. New Phytol. 138, 107-116.

de Boer, W., Li, X., Meisner, A., and Garbeva, P. (2019). Pathogen suppression by microbial volatile organic compounds in soils. FEMS Microbiol. Ecol. 95:fiz105. doi: 10.1093/femsec/fiz105

de Boer, W., Wagenaar, A. M., Klein Gunnewiek, P. J., and van Veen, J. A. (2007). In vitro suppression of fungi caused by combinations of apparently nonantagonistic soil bacteria. FEMS Microbiol. Ecol. 59, 177-185. doi: 10.1111/j. 1574-6941.2006.00197.x

Dignam, B. E. A., O’Callaghan, M., Condron, L. M., Kowalchuk, G. A., Van Nostrand, J. D., Zhou, J., et al. (2018). Effect of land use and soil organic matter quality on the structure and function of microbial communities in pastoral soils: implications for disease suppression. PLoS One 13:e0196581. doi: 10.1371/journal.pone.0196581

Ellert, B., and Bettany, J. (1995). Calculation of organic matter and nutrients stored in soils under contrasting management regimes. Can. J. Soil Sci. 75, $529-538$.

European Commission (2017). On Member State National Action Plans and on Progress in the Implementation of Directive 2009/128/EC on the Sustainable use of Pesticides. Report from the Commission to the European Parliament and the Council. $\operatorname{COM}(2017) 587$ final, Brussels: European Commission.

Friberg, H., Persson, P., Jensen, D. F., and Bergkvist, G. (2019). Preceding crop and tillage system affect winter survival of wheat and the fungal communities on young wheat roots and in soil. FEMS Microbiol. Lett. 366:fnz189. doi: 10.1093/ femsle/fnz189 
Garbeva, P., Hol, W., Termorshuizen, A. J., Kowalchuk, G. A., and de Boer, W. (2011). Fungistasis and general soil biostasis-A new synthesis. Soil Biol. Biochem. 43, 469-477. doi: 10.1016/j.soilbio.2010.11.020

Heikkinen, J., Ketoja, E., Nuutinen, V., and Regina, K. (2013). Declining trend of carbon in Finnish cropland soils in 1974-2009. Glob. Chang. Biol. 19, 1456-1469. doi: 10.1111/gcb.12137

Hietaniemi, V., Rämö, S., Yli-Mattila, T., Jestoi, M., Peltonen, S., Kartio, M., et al. (2016). Updated survey of Fusarium species and toxins in Finnish cereal grains. Food Addit. Contam. Part A Chem. Anal. Control Expo. Risk Assess. 33, 831-848. doi: 10.1080/19440049.2016.1162112

Hofgaard, I. S., Seehusen, T., Aamor, H. U., Riley, H., Razzghian, J., Le, V. H., et al. (2016). Inoculum potential of Fusarium spp. relates to tillage and straw management in Norwegian fields of spring oats. Front. Microbiol. 7:556. doi: $10.3389 /$ fmicb.2016.00556

IUSS Working Group WRB (2006). World Reference Base for Soil Resources: A Framework for International Classification, Correlation and Communication. World Soil Resources Reports 103, Rome: FAO.

Janvier, C., Villeneuve, F., Alabouvette, C., Edel-Hermann, V., Mateille, T., and Steinberg, C. (2007). Soil health through soil disease suppression: which strategy from descriptors to indicators? Soil Biol. Biochem. 39, 1-23. doi: 10.1016/j. soilbio.2006.07.001

Kassam, A., Friedrich, T., and Derpsch, R. (2019). Global spread of conservation agriculture. Int. J. Environ. Stud. 76, 29-51. doi: 10.1080/00207233.2018. 1494927

Kaukoranta, T., Hietaniemi, V., Rämö, S., Koivisto, T., and Parikka, P. (2019). Contrasting responses of T-2, HT-2 and DON mycotoxins and Fusarium species in oat to climate, weather, tillage and cereal intensity. Eur. J. Plant Pathol. 155, 93-110. doi: 10.1007/s10658-019-01752-59

Knudsen, I., Debosz, K., Hockenhull, J., Jensen, D. F., and Elmholt, S. (1999). Suppressiveness of organically and conventionally managed soils towards brown foot rot of barley. Appl. Soil Ecol. 12, 61-72.

Laine, M., Rütting, T., Alakukku, L., Palojärvi, A., and Strömmer, R. (2018). Process rates of nitrogen cycle in uppermost topsoil after harvesting in notilled and ploughed agricultural clay soil. Nutr. Cycl. Agroecosyst. 110, 39-49. doi: 10.1007/s10705-017-9825-22

Legrand, F., Chen, W., Cobo-Diaz, J. F., Picot, A., and Le Floch, G. (2019). Co-occurrence analysis reveal that biotic and abiotic factors influence soil fungistasis against Fusarium graminearum. FEMS Microbiol. Ecol. 95, 1-13. doi: $10.1093 /$ femsec/fiz056

Lockwood, J. L. (1977). Fungistasis in soils. Biol. Rev. 52, 1-43. doi: 10.1111/j.1469185X.1977.tb01344.x

Mendes, R., Kruijt, M., de Bruijn, I., Dekkers, E., van der Voort, M., and Schneider, J. H. M. (2011). Deciphering the rhizosphere microbiome for disease-suppressive bacteria. Science 332, 1097-1100. doi: 10.1126/science. 1203980

Muukkonen, P., Hartikainen, H., Lahti, K., Särkelä, A., Puustinen, M., and Alakukku, L. (2007). Influence of no-tillage on the distribution and lability of phosphorus in clay soils. Agric. Ecol. Environ. 120, 299-306. doi: 10.1016/j.agee. 2006.09.012

Nelson, P. E., Toussoun, T. A., and Marasas, W. F. O. (1983). Fusarium Species: An Illustrated Manual for Identification. Pennsylvania, PA: Pennsylvania State University Press.

Oerke, E.-C. (2006). Crop losses to pests. J. Agric. Sci. 144, 31-43. doi: 10.1017/ S0021859605005708

Official Statistics of Finland (2020). Yield of the Main Crops. Available online at: http://stat.luke.fi/en/crop-production-statistics (accessed September 27, 2020).

Ogle, S. M., Alsaker, C., Baldock, J., Bernoux, M., Breidt, F. J., McConkey, B., et al. (2019). Climate and soil characteristics determine where no-till management can store carbon in soils and mitigate greenhouse gas emissions. Sci. Rep. 9:11665. doi: 10.1038/s41598-019-47861-7

Parikka, P., Hakala, K., and Tiilikkala, K. (2012). Expected shifts in Fusarium species' composition on cereal grain in Northern Europe due to climatic change. Food Addit. Contam. Part A Chem. Anal. Control Expo. Risk Assess. 29, 1543-1555. doi: 10.1080/19440049.2012.680613

Penton, C. R., Gupta, V. V. S. R., Tiedje, J. M., Neate, S. M., Ophel-Keller, K., Gillings, M., et al. (2014). Fungal community structure in disease suppressive soils assessed by 28S LSU gene sequencing. PLoS One 9:e93893. doi: 10.1371/ journal.pone.0093893
Postma, J., Schilder, M. T., Bloem, J., and van Leeuwen-Haagsma, W. K. (2008). Soil suppressiveness and functional diversity of the soil microflora in organic farming systems. Soil Biol. Biochem. 40, 2394-2406. doi: 10.1016/j.soilbio.2008. 05.023

Prestele, R., Hirsch, A. L., Davin, E. L., Seneviratne, S. I., and Verburg, P. H. (2018). A spatially explicit representation of conservation agriculturefor application in global change studies. Glob. Chang. Biol. 24, 4038-4053. doi: 10.1111/gcb.14307

Regina, K., and Alakukku, L. (2010). Greenhouse gas fluxes in varying soils types under conventional and no-tillage practices. Soil Tillage Res. 109, 144-152. doi: 10.1016/j.still.2010.05.009

Sharma-Poudyal, D., Schlatter, D., Yin, C., Hulbert, S., and Paulitz, T. (2017). Longterm no-till: a major driver of fungal communities in dryland wheat cropping systems. PLoS One 12:e0184611. doi: 10.1371/journal.pone.0184611

Siegel-Hertz, K., Edel-Hermann, V., Chapelle, E., Terrat, S., Raaijmakers, J. M., and Steinberg, C. (2018). Comparative microbiome analysis of a Fusarium wilt suppressive soil and a Fusarium wilt conducive soil from the Châteaurenard Region. Front. Microbiol. 9:568. doi: 10.3389/fmicb.2018. 00568

Singh, P., Heikkinen, J., Ketoja, E., Nuutinen, V., Palojärvi, A., Sheehy, J., et al. (2015). Tillage and crop residue management methods had minor effects on the stock and stabilization of topsoil carbon in a 30-year field experiment. Sci. Total Environ. 518-519, 337-344. doi: 10.1016/j.scitotenv.2015.03.027

Sipilä, T. P., Yrjälä, K., Alakukku, L., and Palojärvi, A. (2012). Cross-site soil microbial communities under tillage regimes: fungistasis and microbial biomarkers. Appl. Environ. Microbiol. 78, 8191-8201. doi: 10.1128/AEM. 02005-12

Soussana, J.-F., Lutfalla, S., Ehrhardt, F., Rosenstock, T., Lamanna, C., Havlík, P., et al. (2019). Matching policy and science: rationale for the ' 4 per 1000 soils for food security and climate' initiative. Soil Tillage Res. 188, 3-15. doi: 10.1016/j.still.2017.12.002

Toyota, K., and Shira, S. (2018). Growing interest in microbiome research unraveling disease suppressive soils against plant pathogens. Microbes Environ. 33, 345-347. doi: 10.1264/jsme2.ME3304rh

Tyc, O., van den Berg, M., Gerards, S., van Veen, J. A., Raaijmakers, J. M., de Boer, W., et al. (2014). Impact of interspecific interactions on antimicrobial activity among soil bacteria. Front. Microbiol. 5:567. doi: 10.3389/fmicb.2014.00567

van Agtmaal, M., Straathof, A., Termorshuizen, A., Teurlincx, S., Hundscheid, M., Ruyters, S., et al. (2017). Exploring the reservoir of potential fungal plant pathogens in agricultural soil. Appl. Soil Ecol. 121, 152-160. doi: 10.1016/j. apsoil.2017.09.032

van Agtmaal, M., Straathof, A. L., Termorshuizen, A., Lievens, B., Hoffland, E., and de Boer, W. (2018). Volatile-mediated suppression of plant pathogens is related to soil properties and microbial community composition. Soil Biol. Biochem. 117, 164-174. doi: 10.1016/j.soilbio.2017.11.015

Vuorinen, J., and Mäkitie, O. (1955). The Method of Soil Testing in use in Finland, Vol. 63. Helsinki: Valtioneuvoston kirjap, 1-44.

Wang, L., and Li, X. (2019). Steering soil microbiome to enhance soil system resilience. Crit. Rev. Microbiol. 45, 5-6. doi: 10.1080/1040841X.2019.1700906

Weller, D. M., Raaijmakers, J. M., Gardener, B. B. M. S., and Thomashow, L. S. (2002). Microbial populations responsible for specific soil suppressiveness to plant pathogens 1. Annu. Rev. Phytopathol. 40, 309-348.

Wendt, J., and Hauser, S. (2013). An equivalent soil mass procedure for monitoring soil organic carbon in multiple soil layers. Eur. J. Soil Sci. 64, 58-65. doi: 10.1111/ejss. 12002

Williams, R. J., Howe, A., and Hofmockel, K. S. (2014). Demonstrating microbial co-occurrence pattern analyses within and between ecosystems. Front. Microbiol. 5:358. doi: 10.3389/fmicb.2014.00358

Conflict of Interest: The authors declare that the research was conducted in the absence of any commercial or financial relationships that could be construed as a potential conflict of interest.

Copyright (c) 2020 Palojärvi, Kellock, Parikka, Jauhiainen and Alakukku. This is an open-access article distributed under the terms of the Creative Commons Attribution License (CC BY). The use, distribution or reproduction in other forums is permitted, provided the original author(s) and the copyright owner(s) are credited and that the original publication in this journal is cited, in accordance with accepted academic practice. No use, distribution or reproduction is permitted which does not comply with these terms. 